\title{
Antagonistic Activity of Bacillus spp. Against Fire Blight Disease In vitro and In planta $^{\#}$
}

\author{
Haris Butt $^{1, \text { a }}$, Kubilay Kurtulus Bastas ${ }^{1, b, *}$ \\ ${ }^{1}$ Department of Plant Protection, Faculty of Agriculture Selçuk University, 42250 Konya, Turkey \\ *Corresponding author
}

A R T I C L I N F O A B S T R A C T

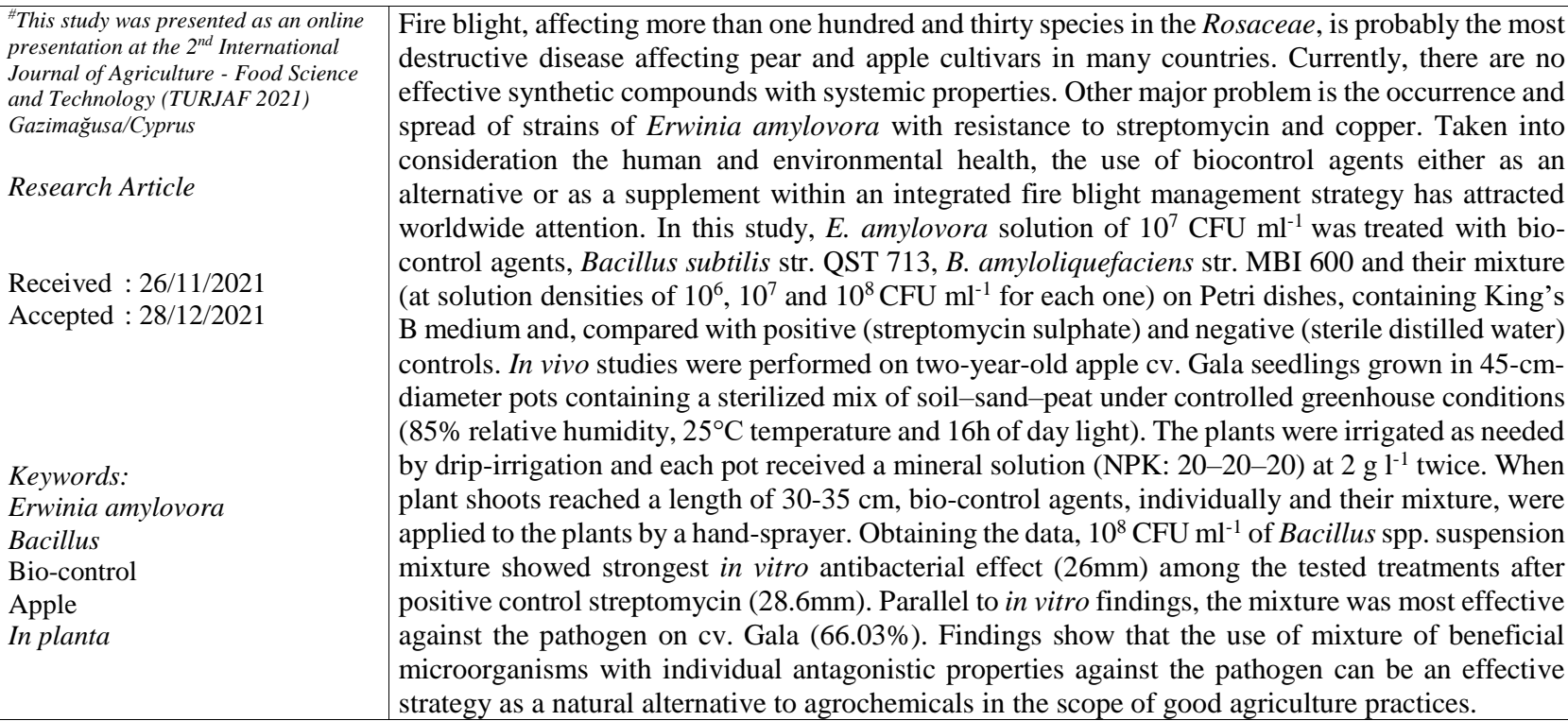

\section{Introduction}

Major factors contributing to global crop losses include biotic stresses such as plant pathogens and pests. Devastating epidemics occur as a result of these pathogens proliferating in plants which severely affect food production especially in developing countries with limited resources. Currently, plant pathogens account for an alarming $8-40 \%$ of global yield losses (Ntushelo et al., 2019). Among such economically important pathogens is the Gram-negative enterobacterium Erwinia amylovora (Burr.), responsible for a devastating fire blight disease of apple and pear and also infecting other genera of the Rosaceae family. E. amylovora was the first bacterium to be identified as a plant pathogen (Bastas, 2016) and it ranks among the most destructive top 10 plant pathogenic bacteria in the world (Borruso et al., 2017). In Turkey, fire blight was first reported in the year 1985 in a pear orchard in Sultandağ 1 district of Afyon province (Öktem and Benlioğlu, 1988) and rapidly spread to other regions within a single growing season. Primarily, the bacterium enters the host through flowers, natural openings or injuries on vegetative parts and moves internally to other sites causing blossom, shoot, and rootstock infections or blight (Peil et al., 2009). Either blossoms, shoots, or the rootstock can show blight symptoms leading to severe economic losses to varying extents. Unintended trade of latently infected plants is responsible for its spread to distant ecological areas, while wind, rain, and pollinating insects disseminate the pathogen to nearby regions (Pester et al., 2012).

The susceptibility of commercial cultivars of the domesticated apple (Malus domestica Borkh.) is very high with some cultivars showing low susceptibility (Sobiczewski et al., 2011). In the early 2000s, \$20-\$100 
million were reported in economic losses due to fire blight outbreaks in pome fruit species (Müge et al., 2020). Destruction of trees to minimize the spread of the pathogen and application of antibiotics in controlling disease in the United States were responsible for such huge losses. Since the use of antibiotics in managing plant diseases is either completely forbidden or regulated strictly in Europe, production costs are mainly responsible for such economic damages (Emeriewen et al., 2019).

Copper compounds are mainly used to control plant disease but the effectiveness of these compounds is insufficient in apple disease management and are known to have negative effects on human and animal health, on the environment and are also phytotoxic to plants. Streptomycin is the most effective chemical against fire blight disease, but it has a short effectiveness period because of the development of resistant strains (Bastas, 2020). Europe has banned the use of antibiotics in apple and pear orchards to eliminate the traces of antibiotics contaminating foods and to minimize the resistance development in bacteria. In addition, its use has been banned by National Organic Standards Board in the United States in organic pear and apple orchards in 2014 (Dagher et al., 2020). To combat fire blight disease, the development of alternative strategies is inevitable that should be eco-friendly and ethically responsible in comparison to the use of hazardous copper compounds and antibiotics. Biological control of plant diseases is one of such practices that is achieved by the use of beneficial microorganisms with antagonistic properties against pathogens, and such microorganisms are referred to as the biological control agent (BCA). The use of BCA either as an alternative to synthetic chemicals or as a supplement has attracted the world to be included in integrated pathogen management programs in different food systems. Various species of different microorganisms such as bacteria, fungi, and viruses have been reported to be beneficial against pathogens. The genus Bacillus among bacterial antagonists has many species reported for their antagonistic relationship with the pathogens, and the number is increasing rapidly (Shafi et al., 2017). Secretion of various cell-wall degrading enzymes by Bacillus spp. such as protease, cellulase, chitosanase, glucanases, lipopeptides, and hydrogen cyanide holds the key to inhibit the growth and development of many plant pathogenic bacteria, fungi, and viruses. Bacillus-induced physiological changes, such as the activation of the antioxidant and defense systems resembles the harmful effects of pathogens on crops. Interaction between Bacillus and plants triggers plant defenses against infections by influencing resistance genes, proteins, phytohormones and metabolites (Butt and Bastas, 2022). Due to their biofertilizer and biocontrol properties, the popularity and importance of these BCA is gradually increasing to be used as a natural alternative to synthetic pesticides and other agrochemicals (Qiao et al., 2014). Commercially available B. subtilis based biopesticides include Avogreen, Ballad, Bio safe, Biosubtilin, Cease, Companion, Ecoshot, FZB 24WG, HiStick N/T/Subtilex/Pro-Mix, Kodiak, Rhapsody, Rhizo Plus, Serenade and B. amyloliquefaciens based products are RhizoVital 42, RhizoVital 42 TB (Fira et al., 2018) and Serifel.
Synergistic interactions between more than one lipopeptide family produced by many strains of the Bacillus species can enhance their biocontrol capacity. Investigations regarding additive, antagonistic, or synergistic effects of different lipopeptides produced simultaneously from particular Bacillus spp. are scarce and need further studies as the mixture of different lipopeptides is considered beneficial in plant protection (Butt and Bastas, 2022). Hence the aim of this study was to evaluate the in vivo and in vitro effect of individual and in mixture applications of the strains $B$. subtilis QST 713 and $B$. amyloliquefaciens MBI 600 against $E$. amylovora on apple cv. Gala.

\section{Material and Methods}

\section{Plant Material}

Two-year-old apple cv. Gala seedlings were grown in a greenhouse in 45-cm-diameter pots containing a sterilized mix of soil-sand-peat (2:1:1 by volume) under controlled greenhouse conditions $\left(85 \%\right.$ relative humidity, $25 \pm 2^{\circ} \mathrm{C}$ temperature and $16 \mathrm{~h}$ of day light). The plants were irrigated as needed by drip-irrigation and each pot received a mineral solution (NPK: 20-20-20) at $2 \mathrm{~g} \mathrm{~L}^{-1}$ twice (Bastas, 2020).

\section{Pathogen Strains and Growth Conditions}

Highly virulent E. amylovora isolates, ArAdy5 (93\%) and ArAdy7 (86\%) used in the assays were obtained from culture collection of the Molecular Plant Bacteriology Laboratory, Department of Plant Protection, Selcuk University. The pathogens were grown in nutrient broth (NB) at $25 \pm 2^{\circ} \mathrm{C}$. Bacterial suspensions were prepared with ArAdy5 and ArAdy7 isolates, 48-hour-old adjusted to $10^{7}$ CFU ml-1 concentrations in a spectrophotometer (Eppendorph Bioplus, OD 600 : 0.15). A mixture of these isolates was used in the experiment and maintained on the ice during the inoculations.

\section{Bacillus Strains and Growth Conditions}

B. subtilis QST 713 and B. amyloliquefaciens MBI 600 were obtained from culture collection of the Molecular Plant Bacteriology laboratory, Department of Plant Protection, Selcuk University and were grown in LB agar medium for $24 \mathrm{hr}$ at $30 \pm 2^{\circ} \mathrm{C}$ before any experimental use.

\section{In vitro studies}

Evaluation of the pathogen inhibition by Bacillus spp.

The antibacterial effect of $B$. subtilis str. QST 713 and B. amyloliquefaciens str. MBI 600 on E. amylovora was investigated in vitro using dual culture method described by Almoneafy et al. (2012). The suspension of $E$.

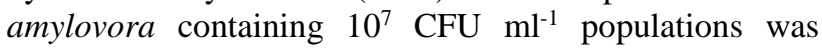
spread to $9.0 \mathrm{~cm}$ diameter petri dishes containing King's B medium. Individual and mixed suspension of test antagonist strains at $10^{6}, 10^{7}$ and $10^{8} \mathrm{CFU} \mathrm{ml}{ }^{-1}$ dilutions were transferred to the center of agar plates using sterile toothpicks. Streptomycin sulphate and sterile water were used as positive and negative control, respectively. Three replications per treatment were setup and the petri dishes containing the pathogen, Bacillus spp. and controls were incubated at $26 \pm 2^{\circ} \mathrm{C}$ for 48 hours. The inhibition zones formed around tested isolates as clear haloes were measured and noted in $\mathrm{mm}$. 


\section{In planta experiments}

Most effective concentration $\left(10^{8} \mathrm{CFU} \mathrm{ml}^{-1}\right)$ of Bacillus spp. observed in in vitro assays in preventing E. amylovora was used in in planta experiments. When plant shoots reached a length of $30-35 \mathrm{~cm}$, bio-control agents, individually and their mixture, were applied to the plants by a hand-sprayer. The apple seedlings were sprayed with bacterial suspensions twice prior to pathogen inoculation with 7 days interval. The plants were kept at $85 \% \mathrm{RH}$, $25 \pm 2^{\circ} \mathrm{C}$ and $16 \mathrm{~h}$ of day light in greenhouse. Twenty-four hours after the second application, the density $\left(\mathrm{CFU} \mathrm{ml}{ }^{-1}\right)$ of Bacillus spp. on host leaves were determined according to Yadav et al. (2010).

Inoculum was prepared from 48-h-old pathogen cultures grown on LB agar medium at $25 \pm 2{ }^{\circ} \mathrm{C}$. The inoculum density was adjusted to $10^{7} \mathrm{CFU} \mathrm{m} \mathrm{m}^{-1}$ in sterile distilled water (SDW) using spectrophotometer (Eppendorph Bioplus, OD 600 : 0.15). Shoots were inoculated, after 24 hours of second treatment with Bacillus strains, by transversally bisecting the two youngest actively growing leaves and dipped for $30 \mathrm{sec}$ in suspension mixture of isolates ArAdy5 and ArAdy7. The treated shoots were labeled with flagging tape for evaluation purposes (Bastas, 2020).

\section{Experimental Design}

In planta experiment was set up in a completely randomized block design with three replicates. A single replicate was a mean from nine shoots on three saplings.

\section{Evaluation of Disease Severity and Treatment Effectiveness On Apple Cv. Gala}

When the fire blight lesions ceased to extend, the length of visible necrosis and healthy shoot lengths were recorded. Percent disease severity (DS) was calculated using the following formula:

$$
\operatorname{DS}(\%)=(\mathrm{a} / \mathrm{b}) \times 100
$$

where ' $a$ ' is the length of the blighted part of the shoot $(\mathrm{cm})$, and ' $b$ ' is the whole length of the shoot $(\mathrm{cm})$ (Aldwinckle et al., 2001; Fernando and Jones, 1999).
Percent effectiveness of the treatments (A) was calculated according to the following formula (Abbott, 1925):

$$
\mathrm{A}(\%)=(\mathrm{B}-\mathrm{C}) / \mathrm{B} \times 100
$$

where ' $\mathrm{B}$ ' is the percent disease severity in the controls, and ' $\mathrm{C}$ ' is the percent disease severity in treated shoots.

\section{Statistical Analysis}

MINITAB ver. 18 program was used for variance analysis and statistical evaluations were done with Tukey multiple comparison test in the MSTAT program to analyze the data obtained (Düzgüneş et al., 1987). Significant differences between the two mean values were computed by their significant levels at $\mathrm{P} \leq 0.05$.

\section{Results}

\section{In vitro Studies}

Obtaining the data, the mean values of the inhibition zones ranged from $2.5 \mathrm{~mm}$ to $26 \mathrm{~mm}$ (Table 1). The inhibition zones expanded with increasing concentration of the Bacillus spp. and the maximum inhibition zone (26 $\mathrm{mm}$ ) were obtained with $10^{8} \mathrm{CFU} \mathrm{ml}^{-1}$ solution mixture of both Bacillus strains with no significant difference to 28.6 $\mathrm{mm}$ inhibition zone formed by streptomycin (Table 1 and Figure 1). It was followed by B. subtilis str. QST 713 (19.6 $\mathrm{mm})$ at $10^{8} \mathrm{CFU} \mathrm{m} \mathrm{m}^{-1}$. The lowest inhibition zones of 2.5 $\mathrm{mm}, 3.8 \mathrm{~mm}$ and $4 \mathrm{~mm}$ were obtained by $10^{6}, 10^{7}$ and $10^{8}$ CFU ml ${ }^{-1}$ concentrations of B. amyloliquefaciens MBI 600 , respectively.

\section{In planta Experiments}

After two treatments of the leaves of cv. Gala with Bacillus spp., the highest bacterial population density was obtained with the mixture of Bacillus strains $\left(1.2 \times 10^{9}\right.$ CFU ml $\left.{ }^{-1}\right)$, followed by str. QST713 $\left(8.5 \times 10^{7} \mathrm{CFU} \mathrm{ml}^{-1}\right)$ and str. MBI600 $\left(2.9 \times 10^{7} \mathrm{CFU} \mathrm{ml}^{-1}\right)$ (Table 2 and Fig. 2).

Parallel to in vitro findings, the mixture of Bacillus strains was most effective against the pathogen when applied to the apple cv. Gala $(66.03 \%)$ followed by individual treatments with Bacillus subtilis str. QST713 $(54.75 \%)$ and B. amyloliquefaciens str. MBI 600 (47.01\%) (Table 2 and Figure 3). All the treatments were significantly different from each other at $\mathrm{P} \leq 0.01$.

Table 1. In vitro antibacterial effects of Bacillus spp. against E. amylovora by dual culture method

\begin{tabular}{l|cc}
\hline \multicolumn{1}{c|}{ Treatments } & Concentration $\left(\mathrm{CFU} \mathrm{m}{ }^{-1}\right)$ & Inhibition Zone $(\mathrm{mm})$ \\
\hline Positive Control (Streptomycin) & - & $28.6^{\mathrm{a}}$ \\
Negative Control (SDW) & - & $0.0^{\mathrm{e}}$ \\
& $10^{6}$ & $10.16^{\mathrm{c}}$ \\
Bacillus subtilis QST 713 & $10^{7}$ & $12.6^{\mathrm{c}}$ \\
& $10^{8}$ & $19.6^{\mathrm{b}}$ \\
& $10^{\mathrm{b}}$ & $2.5^{\mathrm{de}}$ \\
B. amyloliquefaciens MBI 600 & $10^{7}$ & $3.8^{\mathrm{d}}$ \\
& $10^{8}$ & $4.0^{\mathrm{d}}$ \\
Bacillus subtilis QST 713+ & $10^{6}$ & $13.3^{\mathrm{c}}$ \\
B. amyloliquefaciens MBI 600 & $10^{7}$ & $18.3^{\mathrm{b}}$ \\
\hline
\end{tabular}

*The same letters next to the mean values $(\mathrm{n}=3)$ in the column indicate that the difference between the applications is not statistically significant (Tukey multiple comp. test, $\mathrm{P} \leq 0.05$ ) 
Table 2. Disease severity (\%) and the efficacy (\%) of Bacillus spp. against fire blight disease on apple cv. Gala seedlings

\begin{tabular}{l|ccc}
\hline \multicolumn{1}{c|}{ Treatments } & $\begin{array}{c}\text { Bacillus spp. on apple cv. } \\
\text { Gala leaves after 2 } \\
\text { application } \\
(\text { CFU ml }\end{array}$ & $\begin{array}{c}\text { Disease } \\
\text { Severity } \\
(\%)\end{array}$ & $\begin{array}{c}\text { Effectiveness } \\
\text { of Treatment } \\
(\%)\end{array}$ \\
\hline Bacillus subtilis QST713 & $8.5 \times 10^{7 \mathrm{~b}}$ & $45.25^{\mathrm{b}}$ & $54.75^{\mathrm{c}}$ \\
B. amyloliquefaciens MBI600 & $2.9 \times 10^{7 \mathrm{c}}$ & $52.99^{\mathrm{b}}$ & $47.01^{\mathrm{c}}$ \\
B. subtilis QST713+B. amyloliquefaciens MBI600 & $1.2 \times 10^{9 \mathrm{a}}$ & $33.97^{\mathrm{c}}$ & $66.03^{\mathrm{b}}$ \\
Control (Streptomycin) & - & $19.86^{\mathrm{d}}$ & $80.14^{\mathrm{a}}$ \\
Control (Water) & - & $100.0^{\mathrm{a}}$ & - \\
\hline
\end{tabular}

*The same letters next to the mean values $(n=3)$ in the column indicate that the difference between the applications is not statistically significant (Tukey multiple comp. test, $\mathrm{P} \leq 0.05$ )

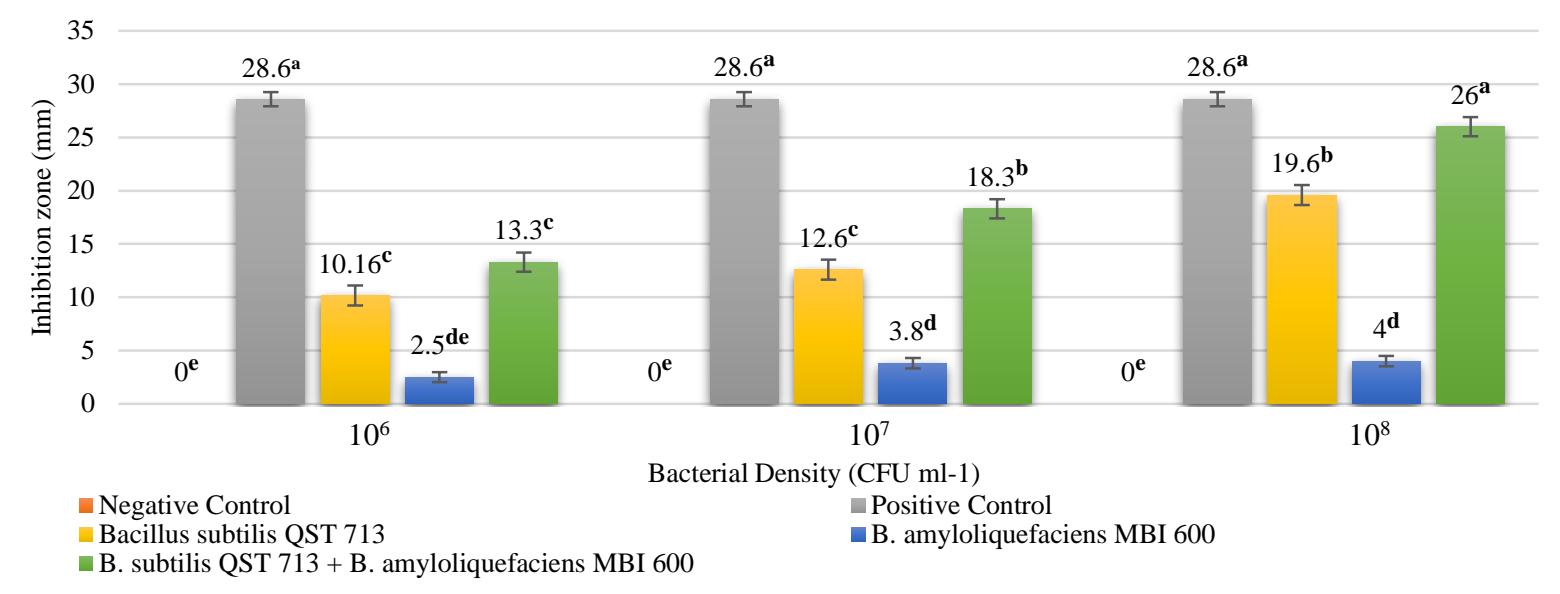

Figure 1. In vitro antagonistic effects of Bacillus spp. against E. amylovora by dual culture method

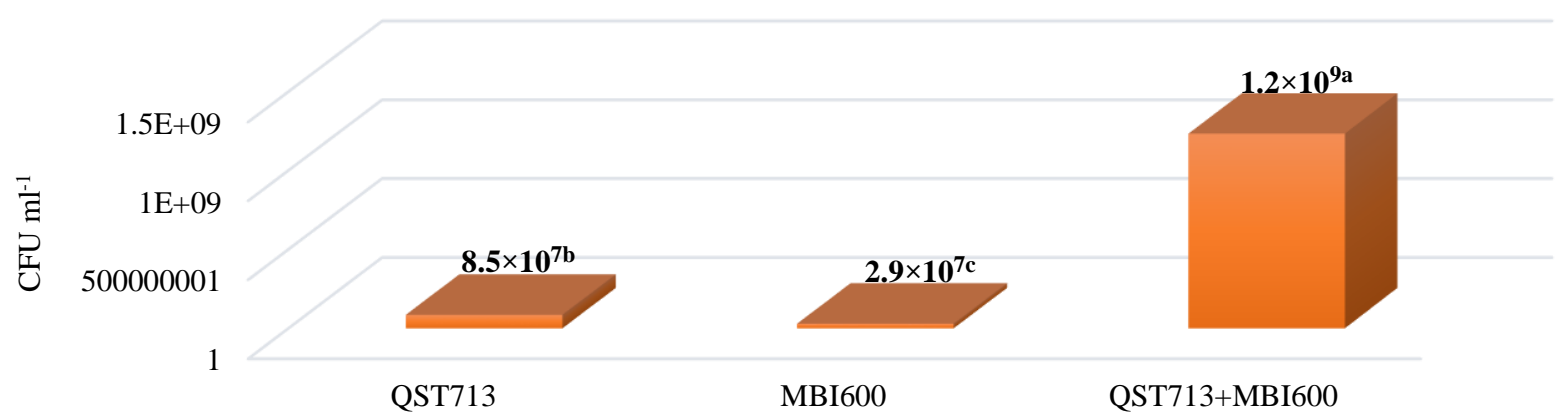

Figure 2. Bacillus densities $\left(\mathrm{CFU} \mathrm{m} \mathrm{m}^{-1}\right)$ recovered from apple cv. Gala leaves after second application.

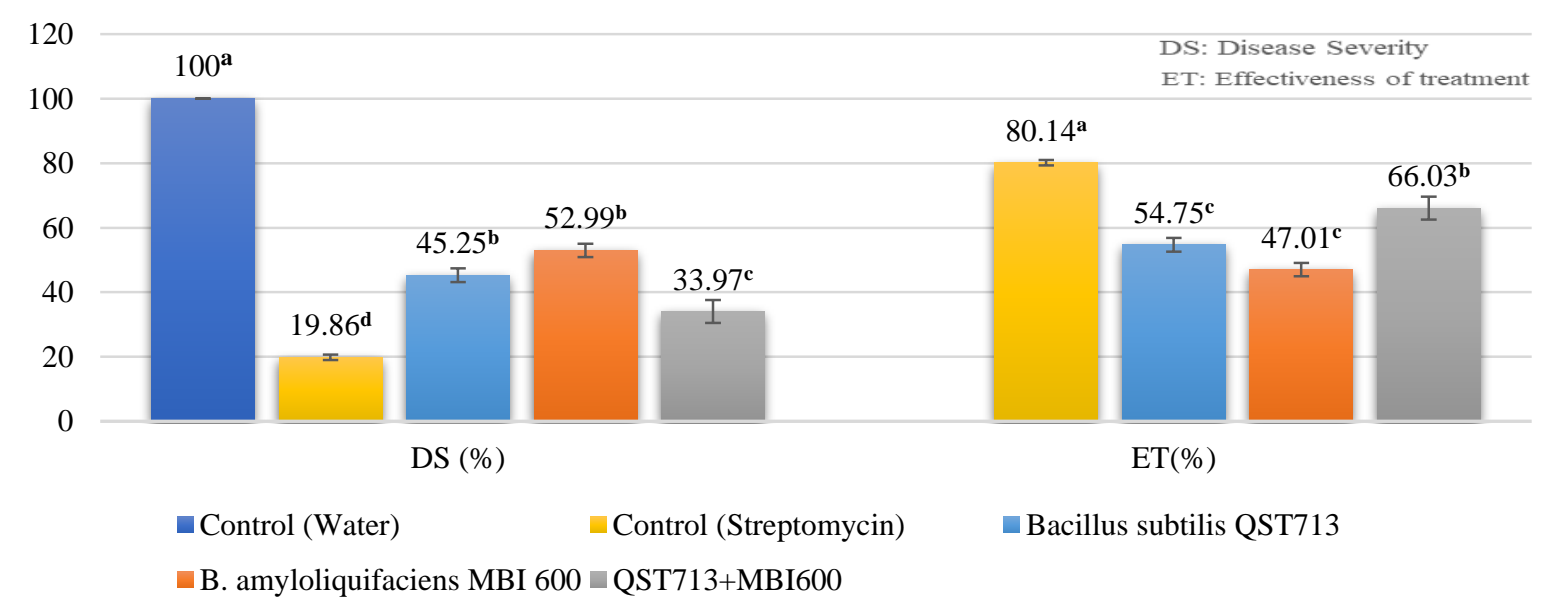

Figure 3. Efficacy of Bacillus spp. against E. amylovora and disease severity on apple cv. Gala 


\section{Discussion}

E. amylovora ranks among the top 10 plant pathogenic bacteria in the world (Borruso et al., 2017), and it cause losses of more than $\$ 100$ million per year (Norelli et al., 2003; Müge et al., 2020). Commercial production of apple and pear is still challenged by this devastating pathogen throughout the world (Ngugi et al., 2011). As the current control practices are ineffective or insufficient and are not reliable, fight against fire blight outbreak is still very difficult (Sundin et al., 2009). The use of bacteria as biological control agents (BCAs) has received more attention due to their versatile modes of action in protecting plants and their potential to be a part of an integrated control strategy (Bahadou et al., 2017). Having the capability to minimize the applications of hazardous chemical compounds, this alternative can provide a powerful and eco-friendly control of this bacterial threat (Finkel et al., 2017: Bahadou et al., 2017).

Many strains of Bacillus subtilis and Bacillus amyloliquefaciens, and the others have been reported to interact with host plants and produce beneficial effects including fire blight disease suppression (Choudhary and Johri, 2009; Kabeil et al., 2010; Gerami et al., 2013; Rosello et al., 2013). B. subtilis is the most studied biocontrol agent, which has been reported as a growth promoter and as antagonistic to a variety of pathogens in vitro and in greenhouse and field studies. B. subtilis, as a disease suppressor, adopt various mechanisms such as antibiosis, lysis of pathogen hyphae, competition for space and nutrients, plant growth promotion (PGP), and induced systemic resistance (ISR). Bacillus subtilis str. QST713 (Serenade) is one of the registered and currently available biopesticide to protect apple and pear trees during blooming (Mikicinski et al., 2016). B. amyloliquefaciens associated with plants is known for their indirect support to plant growth as it can suppress the disease by producing a variety of enzymes and secondary metabolites such as chitinase involved in microbial antagonism. In addition, development of plant resistance was enhanced by $B$. amyloliquefaciens FZB24 against competitive pathogenic bacteria and fungi (Jamal et al., 2018).

Strains of B. amyloliquefaciens have been reported to be 95\% effective against E. amylovora in some apple cultivars (Bahadou et al., 2018). In another work, commercial strain of B. subtilis str. QST713 was $64.3 \%$ efficient in controlling blossom blight against fire blight (Aldwinckle et al., 2018). Chen et al. (2009) has proposed the use of $B$. amyloliquefaciens strains with enhanced synthesis of difficidin and/or bacilysin for development of efficient biocontrol agents against fire blight disease. Antagonistic activity was shown by $B$. amyloliquefaciens subsp. plantarum str. FL50S against E. amylovora both in vitro and in planta (Dagher et al., 2021). Synthesis of several cyclic lipopeptides (cLPs) genes like bmyB (bacillomycin), ituC (iturin), srfAA (surfactin), and fenD (fengycin) by strains of B. subtilis and B. amyloliquefaciens is key to their strong antibacterial activity against $E$. amylovora and several other pathogens (Mora et al., 2015).

In our experiment, in vitro and in planta effectiveness of two different Bacillus strains, individually and in mixture, was evaluated for the first time against fire blight disease in Turkey. In addition, to the best of our knowledge, there is no report in the literature of strains of B. subtilis and B. amyloliquefaciens being used as a mixture against $E$. amylovora.

Our results indicate that the effectiveness of the mixture of the Bacillus strains against E. amylovora is significantly high, in both in vitro and in planta experiments, then the individual treatments. Interestingly, the population density of Bacillus spp. recovered from the leaves of mixture treated apple cv. Gala was greatly higher than the individual treatments. This might be the result of possible synergistic relationship between the two that help them thrive way more efficiently in comparison to their individual survival. Furthermore, in planta effectiveness of str. QST 713 against the pathogen was in parallel to the in vitro findings as expected. On the other hand, an unexpected high in planta effectiveness was shown by the str. MBI 600 as compared to its very low ability to inhibit the pathogen growth in vitro. Probable reason can be the activation of host plant defenses against E. amylovora by the str. MBI 600 as it came in contact with the host.

The application of BCAs, at least $24 \mathrm{~h}$ before the arrival of the pathogen has always been more successful. This gives enough time to the antagonist to fight the pathogen by establishing its own niche first in the site of infection. However, eco-physiological traits of BCAs must be powerful enough to survive under varying field conditions and competitors' indigenous microflora as various factors are continuously altering the environmental conditions. Consequently, numerous works have emphasized the importance of assessing the performance of BCAs under conditions close to field in order to improve their fitness and effectiveness (Daranas et al., 2018). In order to give sufficient amount of time to the Bacillus species to colonize the plant, pathogen inoculation was carried out 24 hours after the last application of test bacteria, and in accordance with the literature report, it obtained more successful results than the pathogen and Bacillus applications at the same time (data not given in this study).

It is known that isolates of the pathogen used in our study as a mixture were highly virulent. In connection with this, it seems natural that our results in preventing fire blight using Bacillus spp. have lower results than other studies. Whereas higher and more successful results are expected under natural infection conditions. This should be tested in regions with different climatic and ecological conditions and with different strains of the pathogen.

Investigations regarding additive, antagonistic, or synergistic effects of different Bacillus spp. are scarce and need further studies as the mixture of different lipopeptides from Bacillus spp. is considered beneficial in plant protection (Butt and Bastas, 2022). Further studies are required using two or more different bacterial antagonists at different concentrations, under different ecological conditions, specially under field conditions in order to find more effective combinations of BCAs against different $E$. amylovora strains.

\section{References}

Abbott WS. 1925. A method of computing the effectiveness of an insecticide. Journal of Economic Entomology, 18(2): 265267. doi: 10.1093/jee/18.2.265a 
Aldwinckle HS, Bhaskara Reddy MV, Norelli JL. 2001. Evaluation of control of fire blight infection of apple blossoms and shoots with SAR inducers, biological agents, a growth regulator, copper compounds, and other materials. Acta Horticulturae, 590: 325-331. doi: 10.17660/ActaHortic.2002.590.48

Almoneafy AA, Xie GL, Tian WX, Xu LH, Zhang GQ, Ibrahim M. 2012. Characterization and evaluation of Bacillus isolates for their potential plant growth and biocontrol activities against tomato bacterial wilt. African journal of Biotechnology, 11(28): 7193-7201. doi: 10.5897/AJB11.2963

Bahadou SA, Ouijja A, Boukhari MA, Tahiri A. 2017. Development of field strategies for fire blight control integrating biocontrol agents and plant defense activators in Morocco. Journal of plant pathology, 51-58.

Bahadou SA, Ouijja A, Karfach A, Tahiri A, Lahlali R. 2018. New potential bacterial antagonists for the biocontrol of fire blight disease (Erwinia amylovora) in Morocco. Microbial pathogenesis, 117: 7-15. doi: 10.1016/j.micpath.2018.02.011

Bastas KK. 2016. Top bacterium since 250 years: Erwinia amylovora (Burr.) winslow et al. Advances in Plants and Agriculture Research, 4(3): 279-281. doi: 10.15406/apar.2016.04.00138

Bastas KK. 2020. Management of Erwinia amylovora by Potential Bio-Pesticides in vitro and in vivo Conditions. Turkish Journal of Agriculture-Food Science and Technology, 8(1): 38-45. doi: 10.24925/turjaf.v8isp1.3845.3933

Borruso L, Salomone-Stagni M, Polsinelli I, Schmitt AO, Benini S. 2017. Conservation of Erwinia amylovora pathogenicityrelevant genes among Erwinia genomes. Archives of microbiology, 199(10): 1335-1344. doi: 10.1007/s00203017-1409-7

Butt H, Bastas KK. 2022. Biochemical and Molecular Effectiveness of Bacillus spp. in Disease Suppression of Horticultural Crops. Sustainable Horticulture: Microbial Inoculants and Stress Interaction. (In press)

Chen XH, Scholz R, Borriss M, Junge H, Mögel G, Kunz S, Borriss R. 2009. Difficidin and bacilysin produced by plantassociated Bacillus amyloliquefaciens are efficient in controlling fire blight disease. Journal of biotechnology, 140(1-2): 38-44. doi: 10.1016/j.jbiotec.2008.10.015

Choudhary DK, Johri BN. 2009. Interactions of Bacillus spp. and plants-with special reference to induced systemic resistance (ISR). Microbiological research, 164(5): 493-513. doi: 10.1016/j.micres.2008.08.007

Dagher F, Nickzad A, Zheng J, Hoffmann M, Déziel E. 2021. Characterization of the biocontrol activity of three bacterial isolates against the phytopathogen Erwinia amylovora. Microbiology Open, 10(3): e1202. doi: 10.1002/mbo3.1202

Dagher F, Olishevska S, Philion V, Zheng J, Déziel E. 2020. Development of a novel biological control agent targeting the phytopathogen Erwinia amylovora. Heliyon, 6(10): e05222. doi: 10.1016/j.heliyon.2020.e05222

Daranas N, Badosa E, Francés J, Montesinos E, Bonaterra A. 2018. Enhancing water stress tolerance improves fitness in biological control strains of Lactobacillus plantarum in plant environments. PLoS One, 13(1): e0190931. doi: 10.1371/journal.pone.0190931

Duzgunes O, Kesici T, Kavuncu O, Gurbuz, F. 1987. Statistical Methods- II. AnkaraUniversity Agriculture Faculty Publishes: 1021, Lesson Book: 295, Ankara, 381pp.

Emeriewen OF, Wöhner T, Flachowsky H, Peil A. 2019. Malus hosts-Erwinia amylovora interactions: strain pathogenicity and resistance mechanisms. Frontiers in plant science, 10: 551. doi: 10.3389/fpls.2019.00551

Fernando WGD, Jones AL. 1998. Prohexadione calcium-a tool for reducing secondary fire blight infection. Acta Horticulturae, 489: 597-600. doi: 10.17660/ ActaHortic.1999.489.103
Finkel OM, Castrillo G, Paredes SH, González IS, Dangl JL. 2017. Understanding and exploiting plant beneficial microbes. Current opinion in plant biology, 38: 155-163. doi: 10.1016/j.pbi.2017.04.018

Fira D, Dimkić I, Berić T, Lozo J, Stanković S. 2018. Biological control of plant pathogens by Bacillus species. Journal of biotechnology, 285: 44-55. doi: 10.1016/ j.jbiotec.2018.07.044

Gerami E, Hassanzadeh N, Abdollahi H, Ghasemi A, Heydari A. 2013. Evaluation of some bacterial antagonists for biological control of fire blight disease. Journal of Plant Pathology, 95(1): 127-134.

Jamal Q, Lee YS, Jeon HD, Kim KY. 2018. Effect of plant growth-promoting bacteria Bacillus amyloliquefaciens $\mathrm{Y} 1$ on soil properties, pepper seedling growth, rhizosphere bacterial flora and soil enzymes. Plant Protection Science, 54(3): 129137. doi: 10.17221/154/2016-PPS

Kabeil SS, Fayed MI, Amar MA, Al-Far, IM. 2010. Antagonistic activity of some bacterial isolates against Erwinia amylovora. American-Eurasian Journal of Agricultural and Environmental Science, 8(5): 588-596.

Mikiciński A, Sobiczewski P, Puławska J, Maciorowski R. 2016. Control of fire blight (Erwinia amylovora) by a novel strain 49M of Pseudomonas graminis from the phyllosphere of apple (Malus spp.). European Journal of Plant Pathology, 145(2): 265-276. doi: 10.1007/s10658-015-0837-y

Mora I, Cabrefiga J, Montesinos E. 2015. Cyclic lipopeptide biosynthetic genes and products, and inhibitory activity of plantassociated Bacillus against phytopathogenic bacteria. PLoS One, 10(5): e0127738. doi: 10.1371/ journal. pone.0127738

Müge Ş, Adalet M, Hatice Ö. 2020. Determination of fire blight (Erwinia amylovora) susceptibility in Turkey's Cydonia oblonga Mill. Germplasm. European Journal of Plant Pathology, 157(2): 227-237. doi: 10.1007/s10658-020-01971-5

Ngugi HK, Lehman BL, Madden LV. 2011. Multiple treatment meta-analysis of products evaluated for control of fire blight in the eastern United States. Phytopathology, 101(5): 512522. doi: 10.1094/PHYTO-08-10-0221

Norelli JL, Holleran HT, Johnson WC, Robinson TL, Aldwinckle HS. 2003. Resistance of Geneva and other apple rootstocks to Erwinia amylovora. Plant disease, 87(1): 26-32.

Ntushelo K, Ledwaba LK, Rauwane ME, Adebo OA, Njobeh PB. 2019. The mode of action of Bacillus species against Fusarium graminearum, tools for investigation, and future prospects. Toxins, 11(10): 606. doi: 10.3390/toxins11100606

Öktem YE, Benlioglu K. 1988. Studies on fire blight [Erwinia amylovora (Burr.) Winsl. et al.] of pome fruits. Journal of Turkish Phytopathology, 17: 106.

Peil A, Bus V, Geider K, Richter K, Flachowsky H, Hanke MV. 2009. Improvement of fire blight resistance in apple and pear. International Journal of Plant Breeding, 3(1): 1-27.

Pester D, Milčevičová R, Schaffer J, Wilhelm E, Blümel S. 2012. Erwinia amylovora expresses fast and simultaneously hrp/dsp virulence genes during flower infection on apple trees. PLoS One, 7(3): e32583. doi: 10.1371/journal.pone.0032583

Qiao JQ, Wu HJ, Huo R, Gao XW, Borriss R. 2014. Stimulation of plant growth and biocontrol by Bacillus amyloliquefaciens subsp. plantarum FZB42 engineered for improved action. Chemical and Biological Technologies in Agriculture, 1(1): 1-14. doi: 10.1186/s40538-014-0012-2

Roselló G, Bonaterra A, Francés J, Montesinos L, Badosa E, Montesinos E. 2013. Biological control of fire blight of apple and pear with antagonistic Lactobacillus plantarum. European Journal of Plant Pathology, 137(3): 621-633. doi: 10.1007/s10658-013-0275-7

Shafi J, Tian H, Ji M. 2017. Bacillus species as versatile weapons for plant pathogens: a review. Biotechnology \& Biotechnological Equipment, 31(3): 446-459. doi: $10.1080 / 13102818.2017 .1286950$ 
Sobiczewski P, Mikiciński A, Lewandowski M, Żurawicz E, Peil A, Richter K, Kellerhals M. 2011. Selection for fire blight resistance of apple genotypes originating from European genetic resources and breeding programs. Acta horticulturae, (896): 399-405. doi: 10.17660/ActaHortic.2011.896.57
Sundin GW, Werner NA, Yoder KS, Aldwinckle HS. 2009. Field evaluation of biological control of fire blight in the eastern United States. Plant Disease, 93(4): 386-394. doi: org/10.1094/PDIS-93-4-0386

Yadav RKP, Kakamanoli K, Vokou D. 2010. Estimating bacterial population on the phyllosphere by serial dilution plating and leaf imprint methods. Ecoprint: An International Journal of Ecology, 17: 47-52. doi: 10.3126/ECO.V17I0.4105 